DOI: https://doi.org/10.3126/njdrs.v18i01.41949

\title{
Assessing Household's Food Security in Patarasi Rural Municipality of Jumla District of Karnali Province, Nepal
}

\author{
Suman Kharel, PhD $^{1}$, Deepak Marahatta ${ }^{2}$, Bhanu Limbu ${ }^{3}$ \\ ${ }^{1}$ Lecturer at Central Department of Rural Development, Tribhuvan University, Nepal \\ ${ }^{2} \mathrm{PhD}$ Scholar at Central Department of Rural Development \\ ${ }^{3}$ Program Associate, World Food Program, Karnali \\ Email: suman.kharel@cdrd.tu.edu.np, deman19@gmail.com, bhanulimbu@gmail.com
}

\begin{abstract}
Food security in mountain areas has always been a matter of concern. The purpose of this study is to examine the food security situation and coping strategies in rural households in a mountain area. Following the descriptive research approach, data is collected through implying household survey, semistructured interview, and observation method. The food security situation is analyzed through four dimensions of food security: food availability, access to food, utilization of food, and stability. The result shows households depend mainly on markets as their main source of household food and households follow inadequate food consumption and the majority of households' food consumption patterns constitute either borderline or poor. Households apply short-term food consumption coping strategies such as lending money from friends or buying food on credit. The study recommends that farming households be supported in terms of both short-term and long-term strategies to improve food production and supply.
\end{abstract}

Key words: Accessibility, availability, coping, food, security, strategy, utilization

\section{Introduction}

A universal definition of food security given by World Food Summit 1996, "Food security exists when all people at all times have physical and economic access to sufficient, safe, and food which meets their dietary needs and food preferences for an active and healthy life" (CFS, 2012). This definition integrates four dimensions of food security viz. access to food, availability of food, the biological utilization of food, and the stability of all these. These factors are interrelated. For instance, having access to food means little if poor health status impinges on people's ability to utilize the food they consume. Likewise, earning income to purchase food (access) matters less if insufficient food is available in markets. And, a wellstocked market is irrelevant to those who do not earn adequate income to assist the required quantity of food to feed throughout the year. For food security to be realized, all four dimensions must be fulfilled simultaneously Nepal food Security monitoring System (WFP, 2009). In this regard, the food security status of the study area is assessed using four dimensions of food security: food availability, food access, utilization, and stability.

While food insecurity exists, it can be coped with in various forms. The term coping is usually applied to farmers who experience a loss or reduction in their direct access to food when harvests fail, or, lose their employment and income and therefore face the threat of hunger or even starvation (Hoorweg \& Foeken, 1988). Food insecurity coping strategies play a crucial role in the development of farm households. However, some strategies seem to be difficult to achieve and are too general among farm households to fulfill food requirements. Though many households adopt some food consumption coping strategies, some coping strategies are likely to be as norms as they do not contribute to improving food

Nepalese Journal of Development and Rural Studies, Volume, 18, 2021 
security among the population, for example eating less preferred foods (Maxwell et al. 2008). Due to varying degrees of wealth among households, different coping behaviors are adopted by households at different poverty levels. In the Mountain ecological zone in Nepal, the bulk of food consumed is from households' production. The average household consumes 53 percent of their production, 40 percent of purchased food, and 7 percent in-kind (NPC, 2013). A study of Nepal Thematic Report on Food Security and Nutrition in 2013 discovered that seasonal food insecurity is most prevalent in mountain areas. Most households living in the Hills or Tarai can smooth their consumption throughout the year. During 2010/11, informal and formal assistance provided to Mountain households was important for smoothing household consumption but only when provided at the right time (NPC, 2013).

Agriculture is the major sector of the Nepalese economy that provides employment opportunities to 66 percent of the total population and contributes about 13 percent of the total foreign trade of the country (DoA, 2013). The contribution of the agriculture sector to GDP is 27.59 percent and the growth rate of the agriculture sector is 2.7 percent in the FY 2017/18 which was 3.2 percent during the past two decades (MoF, 2019). The subsistence nature of agriculture cannot meet the growing food requirements of Nepal's growing population. In 2020, Nepal ranks the 73rd moderate out of 107 countries on the Global Hunger Index (GHI 2020), and Nepal's 2020 Global Hunger Index score is 19.5, considered moderate, down from 37.4 in 2000, showing that despite improvements, food and nutrition insecurity is still cause for concern. The prevalence of undernourishment the percentage of the population with insufficient access to calories regularly fell from 23.6 percent in 2000-2002 to 6.1 percent in 20172019 (GHI 2020). There is no doubt that when the agriculture sector fails to perform well, the issue of food insecurity emerges.

The Karnali province is characterized by a traditional rain-fed farming system and rainfall fluctuations assemble with difficult management of crops cultivation that often leads to varying in production, thereby impacting on the food security of the households. Moreover, the region is considered chronic food insecure due to low and insufficient production. The majority of rural mountain's households are facing a problem of food deficit due to the low access to food, lack of access to credit, high reliance on small-size and rain-fed agricultural holdings, high susceptibility to drought, limited access to basic service, lack of access to market, land degradation and decreased productivity, lack of access to technology and lack of access to information on the market, agricultural technology (WFP, 2016). Therefore, households have to adjust their food consumption by cutting the size and frequency of meals and changing their food diet (DDC, 2015). This study intends to carry out an in-depth analysis of the household-level food security situation to understand the causes and severity of the food security situation in the study area. The study also describes and measures the coping strategies when farm households have no access to enough food within and between the seasons. The food security situation in the mountains has complex in terms of severity and coping strategies. Studies in the high mountains often lag capturing their food security situation and complex dynamics of the food system. Therefore, this study fills the research gaps and carries out the food security analysis in the high mountain area of Karnali Province. The objective of the study is to examine the food security situation and coping strategies in rural households of the Jumla District. 


\section{Theoretical Framework}

The research follows the conceptual theory presented below in the diagram (see in Figure 1). To meet the objective of the research, the research assesses and analyzes four dimensions of food security: food availability, access to food, utilization of food, and stability. Further food consumption and coping strategy is addressed through the coping strategy index developed by WFP the coping strategies index manual book.

Figure 1. Conceptual Framework of food security and coping strategies for the study

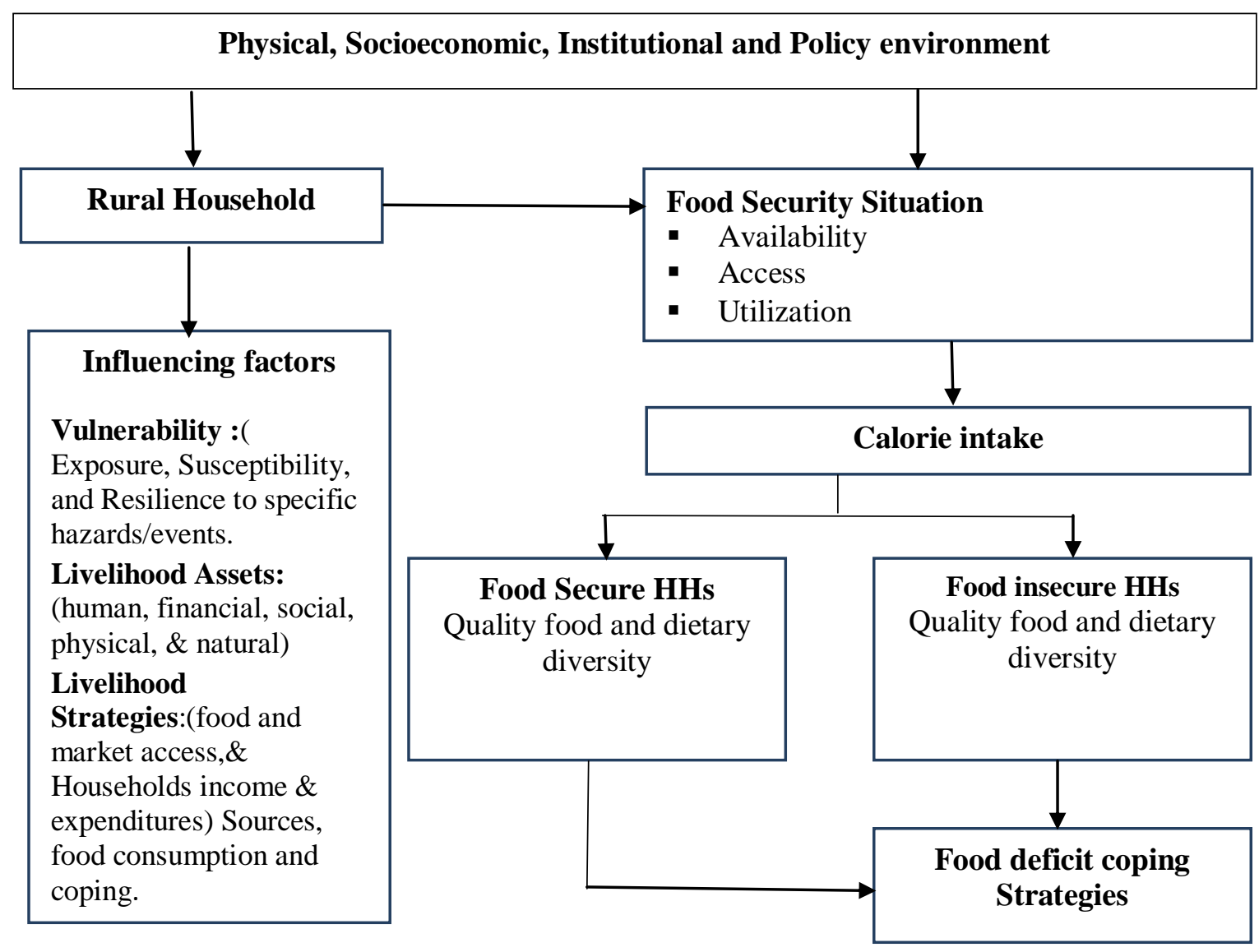

Source:Tefera \& Tefera, 2014

\section{Research Methodology}

Jumla, one of the poorest and remote districts of Nepal, locates in the Karnali province. It has one municipality and seven rural municipalities. The study area Chhumachar village of Patarsi Rural Municipality lies $16 \mathrm{KM}$ away from the district headquarter (DHQ). There is no road connection from the DHQ to Chhumachaur, where is the highest elevation at 3,050 meters in Chhum-jula of Jumla, a record altitude, where rice is cultivated in Nepal. Jumli-Marshi, 'red'-rice a Japonica variety of indigenous rice, having the cold-tolerant gene. There is a high rate of seasonal migration by men to India to cope with chronic food insecurity, especially during winter. People with small landholdings and insufficient food migrate to India before the start of the food-lean period and return during the crop harvesting period. Push factors for seasonal migration are the traditional practice of traveling to sell off handmade garments, NonTimber Forest Products (NTFP) traditional medical herbs and lack of local employment, low agricultural productivity, limited crop season, freezing temperatures, and natural disasters; pull factors include high

Nepalese Journal of Development and Rural Studies, Volume, 18, 2021 
wages in non-agricultural employment and business opportunities in India, in particular in Uttarakhand and Himachal Pradesh. Although local production of edible food per capita has increased in Jumla in the last three years, it still falls short of the basic requirement (DFSN Jumla 2016). Only 8\% of households were food-secure, and households spend on average $31 \%$ of their income on food. The most foodinsecure months are March, July, and August report on the District food security Network report (DFSN Jumla, 2016).

The study follows descriptive research and qualitative research design. A sample of 45 households was selected from a total of 50 households from villages to represent the total population an optimum sample is the one that fulfills the requirement of efficiency, reliability, and flexibility. According to the standard research, design households were selected for a detailed survey using Simple Random Sampling (SRS) design to identify the household for the interview, and sample size for the study was calculated used sample size calculator (http://www.raosoft.com/samplesize.html) with a 5\% margin of error and 95\% confidence level. Quantitative data was collected through a household survey of the community. Similarly, qualitative data were collected through key informant interviews and focus group discussions. Other relevant information was collected through secondary sources as well.

\section{Results and Discussions: Market Access}

In the surveyed areas of the community, all surveyed households lived within 1 - 2 hours from the market mostly used by them. This highlights the difficulties the households face in accessing the markets in these areas. Households have to travel for more than 2 hours to reach the market. Households on average went to market $2-4$ times a month. The roads in this surveyed area function seasonally and recently operate an earth road. In rainy seasons, the river swelling makes the tractors the means of the transportation system. In the rainy season, it results in food stock shortages in the markets due to which the price of the food commodities rises. Based on the interview respondents said that the most critical period of food shortage was July to August because of a lean period of crop harvest, while many families have plenty of food between April and June. Almost all households have sufficient cereal food stock between April and June; likewise fewer households have plenty of food between January and March. Most households often started to purchase foods mainly cereals for home consumption during April May months as stock for the lean period i.e. June to August.

Table 1. Market Access food Commodities $(n=45)$

\begin{tabular}{lcc}
\hline A. What kind of goods are generally sufficiently available in the Market for purchase? \\
\hline kind of Commodities & No. of Household & Percentage \\
Cereals & 45 & $100.0 \%$ \\
Pulse & 37 & $82.2 \%$ \\
Vegetables & 2 & $4.4 \%$ \\
Edible Oil & 45 & $100.0 \%$ \\
Other & 3 & $6.7 \%$ \\
B. Approximately, how many days do you think your current cereal stock will last? \\
No. of Days & No. of Household $\quad$ Percentage \\
30 (1 months) & 2 & \\
60 (2 Months) & 23 & $4.4 \%$ \\
90 (3 Months) & 14 & $51.1 \%$ \\
120 (4 Months) & 2 & $31.1 \%$ \\
180 (6 Months) & 4 & $4.4 \%$ \\
\hline
\end{tabular}

Source: Field Survey, 2019 
The finding shows that the households' main source of all food items depends upon the markets. Table: 1shows cereal rice and oil are only purchased from markets, while other food items such as pulse $82.2 \%$, vegetables $4.4 \%$ and others $6.7 \%$ i.e. tea, sugar, and condiment purchased from the markets and remaining percent relied on their production. This shows the people of this area are not solely dependent on their agriculture production, but on the market too. The data shows the current household food stock in which $4.4 \%$ households have for one month, $51 \%$ have for 2 months, 31.1\% have for 3 months and $4.4 \%$ have for 4 months, and only $8.9 \%$ have sufficient for 6 months.

\section{Availability of Food Stocks (Vulnerability and Shocks)}

Table 2. Availability of Food stocks

\begin{tabular}{lcc}
\hline Status of cereal food production & Frequency & Percentage \\
\hline A. How does your current overall cereal stock level compare with the same time last year? \\
Decrease & 40 & $88.90 \%$ \\
Remain same & 5 & $11.10 \%$ \\
B. If the overall cereal stock level has decreased compared to last year, what is the main reason \\
Lack of or less agricultural inputs & 20 & $48.80 \%$ \\
Drought resulting in crop loss & 21 & $51.20 \%$ \\
Landslide & 2 & $4.80 \%$ \\
Hailstorms & 1 & $2.40 \%$ \\
Less land cultivated than last year & 1 & $2.40 \%$
\end{tabular}

Source: Field Survey, 2019

Table 2 indicates that inadequate rainfall and drought are the main causes of food shortage during the summer season for nearly half $(51.20 \%)$ of the households. Respondents said that despite cultivating droughts resistant crops, the preceding drought was so severe that their crops dried immaturely thus constraining their harvests. This exposed them to vulnerability to household food insecurity. Households had experienced drought(s) in the past two rainy seasons, all the respondents said that drought was the main reason leading to vulnerability. Similarly, uncertain heavy rainfall caused landslides $4.80 \%$ which damaged their farmland, thereby leading to vulnerability. Nearly half of respondents $48.80 \%$ reported that the main reasons for low and insufficient farm production are a lack or fewer agriculture inputs such as improved seeds, fertilizers, and pesticides, traditional technology, weak agricultural extension services, and traditional farming practices. Moreover, the inability to use pesticides had also led to low production because the district is declared an organic district so that farmers have to rely on organic fertilizers which were not sufficient to increase production and productivity.

Households Expenditure on Food and Non-Food Items

Table 3. Household's expenditure on Food and Non-food Items (NPRs) within 30 days

\begin{tabular}{|c|c|c|c|}
\hline Types of Expenditure & HHs Percentage & Average in & Std. Deviation \\
\hline $\begin{array}{l}\text { A. Expenditures on food items by } \\
\text { Household Members }\end{array}$ & & (NPRs) & \\
\hline Expenses on Cereals food & $100 \%$ & 2862.22 & 1325.11 \\
\hline Expenses on Root and Tubers & $13 \%$ & 294.44 & 998.99 \\
\hline Expenses on Fish, Meat, Eggs & $58 \%$ & 616.00 & 898.98 \\
\hline Expenses on Pulses & $27 \%$ & 301.11 & 663.71 \\
\hline $\begin{array}{l}\text { Milk, Cheese, sugar, Tea, and Coffee, } \\
\text { and Expenses on condiments salt, spices }\end{array}$ & $100 \%$ & 938.89 & 630.92 \\
\hline
\end{tabular}

Nepalese Journal of Development and Rural Studies, Volume, 18, 2021 


\begin{tabular}{lccc}
\hline $\begin{array}{l}\text { B. Expenditures on all Non- food items } \\
\text { by Household Members }\end{array}$ & & & \\
$\begin{array}{l}\text { Expenses on transport/communication } \\
\text { Expenses on education, school fee, } \\
\text { uniform, stationary }\end{array}$ & $83 \%$ & 515.56 & 708.70 \\
$\begin{array}{l}\text { Expenses on construction, house repairs, } \\
\text { house rent, firewood, kerosene/electrify }\end{array}$ & $82 \%$ & 1713.78 & 1381.60 \\
$\begin{array}{l}\text { Expenses on medical and health care } \\
\text { Expenses on shoes, clothing, Tobacco }\end{array}$ & $56 \%$ & 264.67 & 779.20 \\
\hline
\end{tabular}

Source: Field Survey, 2019

Table: 3 shows that the costs of Non-food items are higher than those of food items for 30 days. The average expenditure for food items for 30 days is 5,012 NPRs per household. For expenditure on food items, on average, the bulk of the outlays comes from the expenses on cereals food mainly rice. Meat (expenses on fish, meat, eggs) accounts for 58\%, followed by milk, cheese, sugar, tea, and coffee, and expenses on condiments salt, spices. Expenditures on pulses and root and tubers are 13\% and 27\% respectively that comes mostly from their production. The emphasis on cereal purchases also indicates that households do not produce sufficient quantities of such crops. The average expenditure is found to be higher for rural areas of households; this might be attributed to larger household sizes. The average expenditure for non-food items is 7,074 NPRs. High expenditure on non-food item expenses on education including payment of school fee, uniform, stationary expenses on education, uniform, stationery $89 \%$, households also spent on shoes, clothing, tobacco. 82\%, on construction, house repairs, fuel, house rent, firewood, kerosene and electrify. Likewise, $73 \%$ of households had some expenses for transport and communication and $56 \%$ of households had some expenses on medical and health care.

Sources of Food Consumption of Households

Table 4. Sources of Food Consumption of Households in the Last 7 Days

\begin{tabular}{|c|c|c|c|}
\hline \multirow[t]{2}{*}{ Food Types } & \multicolumn{3}{|c|}{ Main Sources of Food Consumption of Households (\%) n=45 } \\
\hline & Own product & Market purchase & Food Consumed in 7 days \\
\hline \multirow[t]{2}{*}{ Cereals } & ( $11 \mathrm{HHs})$ & ( $34 \mathrm{HHs}$ ) & $(45 \mathrm{HHs})$ \\
\hline & $24 \%$ & $76 \%$ & 6.78 Days \\
\hline \multirow[t]{2}{*}{ Pulses (Beans, Peas) } & ( $32 \mathrm{HHs})$ & ( $13 \mathrm{HHs})$ & (44 HHs) \\
\hline & $71 \%$ & $29 \%$ & 4.32 Days \\
\hline \multirow{2}{*}{$\begin{array}{l}\text { Milk and dairy (dairy } \\
\text { products) }\end{array}$} & ( $3 \mathrm{HHs}$ ) & ( $1 \mathrm{HHs})$ & ( $4 \mathrm{HHs})$ \\
\hline & $7 \%$ & $2 \%$ & 2 Days \\
\hline \multirow[t]{2}{*}{ Meat, fish and eggs } & ( $1 \mathrm{HHs})$ & ( $23 \mathrm{HHs})$ & ( $24 \mathrm{HHs})$ \\
\hline & $2 \%$ & $51 \%$ & 1.29 Days \\
\hline \multirow[t]{2}{*}{ Vegetables and leaves } & ( $34 \mathrm{HHs}$ ) & ( $9 \mathrm{HHs})$ & ( $43 \mathrm{HHs}$ ) \\
\hline & $76 \%$ & $20 \%$ & 5.23 Days \\
\hline \multirow[t]{2}{*}{ Fruits } & ( $1 \mathrm{HHs})$ & ( $1 \mathrm{HHs})$ & ( $2 \mathrm{HHs})$ \\
\hline & $2 \%$ & $2 \%$ & 5.5 Days \\
\hline \multirow[t]{2}{*}{ Oils and fats } & (4 HHs) & ( $41 \mathrm{HHs}$ ) & (45 HHs) \\
\hline & $9 \%$ & $91 \%$ & 4.93 Days \\
\hline \multirow[t]{2}{*}{ Sugar, honey } & (4 HHs ) & ( 38 HHs ) & ( $42 \mathrm{HHs}$ ) \\
\hline & $9 \%$ & $84 \%$ & 3.21 Days \\
\hline
\end{tabular}

Source: Field Survey, 2019 
A typical household diet consisted mostly of cereal, pulses, vegetables, milk, meat, oils, and sugar out of which mostly cereals, pulses, and oils are consumed almost daily. Pulses and vegetables are consumed 4 and 5 days a week respectively. But the consumption of nutritious food such as meat products, fruits, and milk and dairy products is found to be low, indicating a poor dietary diversity in the household diet. The households have to rely mostly on the farm and remaining from the markets. 29\% pulses (beans, peas, lentils) are purchased in the market, while $71 \%$ pulse/legumes consumption is obtained from own farm production. This study area pocket for beans and legume production. The source of cereals (rice) is mainly obtained from markets account $76 \%$, while own production covered $20 \%$. Milk and dairy products are mainly from own production $71 \%$ whereas market source account $2 \%$. Meat, fish, and eggs consumption are mainly from markets $51 \%$ and own production $2 \%$. Likewise, the consumption of fruits accounts from markets $2 \%$ and own production $2 \%$. However, the source of vegetable consumption is mainly from own production $76 \%$ and markets $20 \%$. Sugar and honey are purchased from markets $84 \%$ and their products account for only $9 \%$. The source of oils and fats for consumption came from the market $91 \%$ and own production cover only $9 \%$.

\section{Household Food Consumption Score}

Household Food Consumption Score (HFCS) is a frequency-weighted HDDS (IFPRI, 2016). The HFCS is calculated using the frequency of consumption of 8 different food groups consumed: main staples, pulses, vegetables, fruits, meat and fish, milk, sugar, oil. HFCS is measured using standard 7-day food data by classifying food items into food groups; summing the consumption frequencies of food items within the same group (any consumption frequency greater than 7 is recoded as 7; multiplying the value obtained for each food group by its weight).

Table 5. Food Consumption Group Sufficiency $(n=45)$

\begin{tabular}{lcc}
\hline Profile & \multicolumn{2}{l}{ Food Consumption Group Sufficiency } \\
\cline { 2 - 3 } & Frequency & Percentage \\
Inadequate & 33 & $73.33 \%$ \\
Adequate & 12 & $26.67 \%$ \\
Total & 45 & $100.00 \%$ \\
\hline
\end{tabular}

Source: Field Survey, 2019

Food Consumption Score (FCS), an indicator of household-level food access is a composite indicator that takes into account the diet diversity, food frequency, and nutritional importance of food groups consumed by the households. Table: 5shows about $73.33 \%$ of respondents are found to have inadequate food consumption and $26.67 \%$ of households have adequate food consumption dietary diversity.

Table 6.Household Food Consumption Score (HFCS) (n= 45)

\begin{tabular}{|c|c|c|c|c|}
\hline \multirow{2}{*}{\multicolumn{2}{|c|}{ Profile }} & \multicolumn{3}{|c|}{ Food Consumption Groups of Score and Percentage } \\
\hline & & Standard Scale of HFCS & Frequency & Percentage \\
\hline Poor food col & & $0-28$ & 4 & $9 \%$ \\
\hline $\begin{array}{l}\text { Borderline } \\
\text { consumption }\end{array}$ & food & $28.5-42$ & 29 & $64 \%$ \\
\hline $\begin{array}{l}\text { Acceptable } \\
\text { consumption }\end{array}$ & food & $>42$ & 12 & $27 \%$ \\
\hline
\end{tabular}

Source: Field Survey, 2019

Based on the past days' food consumption recalls for the households classified into three categories: Poor, Borderline, and acceptable food consumption are presented in the table: 6 . Table shows,

Nepalese Journal of Development and Rural Studies, Volume, 18, 2021 
9\% of households are found to have poor food consumption patterns. Rice, millet, barley, and wheat are consumed frequently. However, roots and tubers consumed between 2-3 days a week, and lack of fresh vegetables in the diet also implies the risk of micronutrient deficiencies. The second borderline food consumption pattern constitutes $64 \%$ of households and can be broken down into two sub-groups, seasonal period (eg. crop harvest) and accessibility of food in the market. The food security situation often deteriorates during lean season and improves after crop harvest, so domestic production determines the food security situation of the study area. Frequencies of the consumption of different food groups such as cereals, pulses, vegetables, meat, and fish, etc. also vary by season. The consumption of roots and tubers, pulses, and vegetables ranged from 3 to 5 days a week. The majority of respondents consumed these commodities only once a week. The third acceptable food consumption pattern households with good food consumption are found among a total of $27 \%$ of the households.

Coping Strategies Adopted by Households

Table 7. Coping Strategies Adopted by Households ( $n=45)$

\begin{tabular}{lcc}
\hline Coping Strategies & \multicolumn{2}{c}{ Coping strategies adopted by HHs } \\
\cline { 2 - 3 } & Households & Percentage \\
\hline HHs borrow money and food from a formal/informal lender & 40 & $88.89 \%$ \\
Households sale animals (non-productive) than usual & 1 & $2.22 \%$ \\
Households sell household assets/goods & 4 & $8.89 \%$ \\
Households sell productive assets & 3 & $6.76 \%$ \\
Households withdraw children from school & 5 & $11.11 \%$ \\
Households Harvest immature crops & 35 & $77.78 \%$ \\
Households sell last female animals & 4 & $8.89 \%$ \\
Households mortgage house or land & 2 & $4.44 \%$ \\
\hline
\end{tabular}

Source: Field Survey, 2019

Table: 7 shows that households adopted a combination of different coping strategies. During the past 30 days preceding the survey, the households did not have enough food consumption to buy food to feed their families. The first most important coping mechanism used by a large percentage $(88.89 \%)$ of households is to borrow money from a formal/informal lender. They also buy food on credit and also take help from friends or relatives. $77.78 \%$ of households adopted a more severe coping strategy of harvesting immature crops. Besides, severe coping strategies adopted by households include sell of animals (nonproductive) than usual (2.22\%), selling assets/goods (8.89\%), selling productive assets (6.76\%), withdrawing children from school $(11.11 \%)$, selling female animals $(8.89 \%)$ and sell on mortgage house and land $(4.44 \%)$ within last 30 days.

Table 8.Frequency of Coping Strategy Responses - in the last 7 days

\begin{tabular}{lcccc}
\hline Coping Strategy Responses & \multicolumn{3}{c}{ Per week by a of households Response in the last 7 days } \\
\cline { 2 - 5 } & Never & $1-2$ days & $3-6$ days & 7 days \\
$\begin{array}{l}\text { Rely on less preferred, less expensive } \\
\text { food? }\end{array}$ & 6.67 & 91.11 & 2.22 & 0.00 \\
$\begin{array}{l}\text { Borrow food or relied on help from } \\
\text { friends or relatives? }\end{array}$ & 15.56 & 82.22 & 2.22 & 0.00 \\
$\begin{array}{l}\text { Reduce the number of meals eaten per } \\
\text { day? }\end{array}$ & 13.33 & 75.56 & 11.11 & 0.00 \\
$\begin{array}{l}\text { Reduce the portion size of meals? } \\
\begin{array}{l}\text { Reduce the quantities consumed by } \\
\text { adults/mothers for young children? }\end{array}\end{array}$ & 6.66 .67 & 91.11 & 2.22 & 0.00 \\
\hline
\end{tabular}

Nepalese Journal of Development and Rural Studies, Volume, 18, 2021 


\begin{tabular}{llcccc}
\hline $\begin{array}{l}\text { Consume seed stock held for next } \\
\text { season? }\end{array}$ & 57.78 & 42.22 & 0.00 & 0.00 \\
Skip entire days without eating? & & 95.56 & 4.44 & 0.00 & 0.00 \\
\hline
\end{tabular}

Source: Field Survey, 2019

Table 8 shows, in regards to the frequency of coping strategies, about $91.11 \%$ of households indicate that they hardly (less than one to two days a week) applied the strategy of relying on less preferred or less expensive foods. About $2.22 \%$ of households applied the strategy of relying on less preferred and less expensive foods sometimes (three to six days a week), while $82.22 \%$ of households indicated that they applied the strategy of borrowed food or relied on help from friends or relatives foods (less than one to two days a week) and 2.22\% households relied (three to six days a week) on friends and relatives. About $75.56 \%$ of households used the least severe coping strategy of reducing the number of meals eaten per day (less than one to two days a week) and $11.11 \%$ (three to six days a week) at all times as a strategy to mitigate food shortages period. Besides, $33.33 \%$ of households applied a reduction of the quantities consumed by adults and mothers for young children(less than one to two days a week). $42.22 \%$ of households consumed seed stock held for the next planting season. Similarly, $4.44 \%$ of households used the strategy of skipping an entire day without eating as a strategy to overcome food shortages (less than one day a week).

\section{Conclusion}

This study is the first of its kind to study the household food security situation and coping strategies adopted by households. The result shows households depend mainly on markets as their main source of household food as opposed to the usual expectation that their crop production would be the lead source. The result indicates that inadequate rainfall and drought are the main causes of food shortages during the summer season. The majority of households follow inadequate food consumption and the majority of households' food consumption patterns constitute either borderline or poor. The study shows that the majority of the households were significantly more inclined to adopt both food insecurity and coping strategies i.e. Severe and moderately food insecure households were more likely to adopt coping strategies. The first most important coping mechanism used by households is to borrow money from a formal/informal lender or to buy food on credit and take help from friends or relatives. Among the main coping strategies identified is the reduction in the size of meals and a reduction in the number of meals per day. These coping strategies are not detrimental to the household's livelihoods; therefore the households are resilient to food insecurity.

\section{References}

Committee on World Food Security [CFS]. (2012). World food security report.

District Development Committee [DDC]. (2015). Periodic plan of Chhumchura village. DDC, and WFP Nepal Publication.

Department of Agriculture[DoA]. (2013).Annual report. Government of Nepal.

Foeken D.W.J. \& Hoorweg J.C. (1988). Seasonality in the coastal lowlands of Kenya: Part 2: Introduction to seasonality Food and Nutrition Studies Programme no. 28. African Studies Centre.

Global Hunger Index [GHI]. (2020). A closer look at hunger and undernutrition in Nepal. (n.d.). PeerReviewed Annual Publication Designed to Comprehensively Measure and Track Hunger at the Global, Regional, and Country Levels.https://www.globalhungerindex.org/case-studies/2020nepal.html (accessed on December 14, 2020).

International Food Policy Research Institute [IFPRI]. (2016): Global hunger index.

Maxwell, D., Caldwell, R., \& Langworthy, M. (2008). Measuring food insecurity: Can an indicator based on localized coping behaviours be used to compare across context. Food Policy,33, 533-540.

Ministry of Finance [MoF]. (2019). Economic survey 2018/19. Government of Nepal.

Nepalese Journal of Development and Rural Studies, Volume, 18, 2021 
National Planning Commission [NPC].(2013). Nepal thematic report on food security and nutrition, 2013. Central Bureau of Statistics. Government of Nepal.

Tefera, T., \& Tefera, F., (2014). Determinants of households food security and coping strategies for food shortfall in Mareko District, Guraghe Zone Southern Ethiopia. Journal of Food Security, 8.

World Food Programme [WFP]. (2009). A sub regional hunger index for Nepal. Nepal Food Security Monitoring System.

World Food Programme [WFP]. (2016): The NeKSAP food security monitoring Survey, Mid-western and far-western Mountain in Nepal. WFP Nepal.

Nepalese Journal of Development and Rural Studies, Volume, 18, 2021 